\title{
Gene Activation by Cytoplasmic Acidification in Suspension-Cultured Rice Cells in Response to the Potent Elicitor, $\mathrm{N}$-Acetylchitoheptaose
}

\author{
Dao-Yao He, ${ }^{1}$ Yoshiaki Yazaki, ${ }^{2}$ Yoko Nishizawa, ${ }^{3}$ Ryota Takai, ${ }^{4}$ Kosumi Yamada, ${ }^{4}$ Katsuhiro Sakano, ${ }^{2}$ \\ Naoto Shibuya, ${ }^{1}$ and Eiichi Minami ${ }^{1}$ \\ ${ }^{1}$ Laboratory of Glycobiology, Department of Biotechnology, National Institute of Agrobiological Resources, \\ 2-1-2 Kannondai, Tsukuba, 305-8602 Japan; 'Laboratory of Stress Physiology, Department of Plant \\ Physiology, National Institute of Agrobiological Resources, 2-1-2 Kannondai, Tsukuba, 305-8602 Japan; \\ ${ }^{3}$ Laboratory of Gene Engineering, Department of Biotechnology, National Institute of Agrobiological \\ Resources, 2-1-2 Kannondai, Tsukuba, 305-8602 Japan; ${ }^{4}$ Department of Applied Biochemistry, Tsukuba \\ University, Tennoudai, Tsukuba, 305-8572 Japan \\ Accepted 4 September 1998.
}

\begin{abstract}
$N$-Acetylchitoheptaose strongly induces a set of defense reactions in suspension-cultured rice cells including cytoplasmic acidification (K. Kuchitsu, Y. Yazaki, K. Sakano, and N. Shibuya, Plant Cell Physiol. 38:1012-1018, 1997) and the accumulation of mRNAs for two rapidly activated genes, EL2 and EL3 (E. Minami, K. Kuchitsu, D.-Y. He, H. Kouchi, N. Midoh, Y. Ohtsuki, and N. Shibuya, Plant Cell Physiol. 37:563-567, 1996), as well as phenylalanine ammonia-lyase $(P A L)$, chitinase and $\beta$-1,3-glucanase. Treatment of cells with propionic acid resulted in the accumulation of the mRNAs for $E L 2, E L 3$, and $P A L$ in a manner similar to the accumulation induced by $N$ acetylchitoheptaose. Concomitantly, there was a rapid decrease in the cytoplasmic $\mathrm{pH}$ as detected with in vivo ${ }^{31} \mathrm{P}$ nuclear magnetic resonance (NMR) spectroscopy. Interestingly, K-252a, a potent inhibitor of Ser/Thr protein kinases, strongly inhibited gene induction by $\mathrm{N}$-acetylchitoheptaose, but showed much less inhibition of gene induction caused by propionic acid. Calyculin A, a protein phosphatase inhibitor, induced mRNA accumulations for $E L 2, E L 3$ and $P A L$, with concomitant acidification of the cytoplasm. On the other hand, chitinase and $\beta$-glucanase mRNA levels did not change after addition of propionic acid or calyculin A. Treatment of the cells with propionic acid did not induce the production of reactive oxygen species. These results strongly suggest that cytoplasmic acidification at the early stage of elicitor action could be a key step in the signal transduction events leading to the expression of elicitor-responsive genes. A hypothetical model of elicitor signal pathway is proposed based on these results.
\end{abstract}

Additional keywords: protein phosphorylation.

Corresponding author: Eiichi Minami, Laboratory of Glycobiology, Department of Biotechnology, National Institute of Agrobiological Resources, 2-1-2 Kannondai Tsukuba, 305-8602 Japan; Telephone: 81298-38-8364; Fax: 81-298-38-8397; E-mail: eiminami@ abr.affrc.go.jp

The first and second authors equally contributed to this work.
Molecular analysis of plant-microbe interactions has been one of the central research areas of signal transduction in plant cells (for review see Ebel and Cosio 1994; Schultze et al. 1994). When higher plants are attacked by pathogens, a variety of reactions are induced including activation of defenserelated enzymes and accumulation of phytoalexins, both of which are accompanied by gene activation (for review see Dixon and Harrison 1990). For such subjects of analysis, suspension-cultured cells provide an excellent system because of their biochemical and physiological homogeneity. Furthermore, chemicals called elicitors can provoke many of the defense reactions in cultured cells (for review see Cote and Hahn 1994). For these reasons, it has been widely recognized that the combination of elicitors and suspension-cultured cells is a powerful tool to approach the signal transduction from the point of pathogen attack to defense reactions. With this system, extensive studies have been carried out dealing with the molecular mechanisms of activation of defense-related genes focusing on cis and trans factors (Rushton et al. 1996; also see Dixon et al. 1994). Besides these final stages of signal transduction, plant cells exhibit rapid physiological and biochemical reactions upon pathogen or elicitor addition, such as membrane depolarization (Mayer and Ziegler 1988; Kuchitsu et al. 1993), protein phosphorylation/dephosphorylation (Grosskopf et al. 1990; Dietrich et al. 1990; Farmer et al. 1991; Felix et al. 1991, 1993; also see Dixon et al. 1994; Ebel and Cosio 1994; Boller 1995), production of reactive oxygen species (for review see Baker and Orlandi 1995), and change in ion fluxes (Mathieu et al. 1991, 1996; Atkinson et al. 1996; Kikuyama et al. 1997; Kuchitsu et al. 1997). All of these events are believed to be triggered by specific binding of elicitors to putative receptors (Cheong and Hahn 1991; Basse et al. 1993; Shibuya et al. 1993; Baureithel et al. 1994; Nürnberger et al. 1994; also see Boller 1995), and are thought to involve the modification of the plasma membrane.

Cytoplasmic acidification in plant cells has been postulated to be an intracellular signal (see Guern et al. 1991). Transient or sustained cytoplasmic acidification due to $\mathrm{H}^{+}$influx has been observed in several plant cell systems treated with elici- 
tors (Mathieu et al. 1991, 1996; Guern et al. 1992; Kuchitsu et al. 1997), and is considered to be regulated by protein phosphorylation events (Mathieu et al. 1996). However, the biological role of a cytoplasmic acidification remains unclear.

We have developed a model system with suspensioncultured rice cells that strongly react to $\mathrm{N}$-acetylchitooligosaccharides exhibiting transient depolarization of the plasma membrane (Kuchitsu et al. 1993), efflux of $\mathrm{Cl}^{-}$(Kikuyama et al. 1997), efflux of $\mathrm{K}^{+}$and influx of $\mathrm{H}^{+}$(Kuchitsu et al. 1997), and production of reactive oxygen species (Kuchitsu and Shibuya 1994; Kuchitsu et al. 1995). N-acetylchitooligosaccharides of specific structure are required to induce these events. These events also parallel the rapid expression of the EL2 and EL3 genes (Minami et al. 1996), as well as the accumulation of a diterpenoid phytoalexin, Momilactone A (Yamada et al. 1993). It was postulated that rapidly elicited responses (e.g., cytoplasmic acidification) could be involved in signaling the expression of elicitor-responsive genes. In order to address this question, we conducted experiments to test the effects of direct acidification of the cytoplasm with different kinds of acids, while monitoring the accumulation of five classes of elicitor-responsive genes: EL2, EL3, phenylalanine ammonia-lyase $(P A L)$, chitinase, and $\beta$-glucanase. These data indicate that cytoplasmic acidification is a signal for the activation of $E L 2, E L 3$, and $P A L$ (group A) but not for the activation of chitinase and $\beta$-glucanase (group B), and the production of reactive oxygen species. Interestingly, the accumulation of the mRNAs for the group A genes by treatment with propionic acid was much less inhibited by K-252a, a potent inhibitor of Ser/Thr protein kinase, compared with the effect of K-252a on the gene induction by $N$-acetylchitoheptaose. Calyculin A, an inhibitor of protein phosphatase, activated group A genes with concomitant acidification of the cytoplasm, but not group B genes. Based on these results, a hypothetical model for the intracellular signaling pathway is proposed.

\section{RESULTS}

Accumulation of EL2, EL3, and PAL mRNA in response to cytoplasmic acidification by propionic acid and butyric acid.

As a first step in analyzing the role of cytoplasmic acidification in rice cells treated with $\mathrm{N}$-acetylchitooligosaccharides (Kuchitsu et al. 1997), we investigated the effect of propionic acid and butyric acid on the expression of the elicitorresponsive genes. Both of these organic acids have been most commonly used to acidify plant cytoplasm (Guern et al. 1991). Both butyric acid and propionic acid induced the accumulation of the mRNAs for EL2, EL3, and PAL (group A) with kinetics comparable to those of $N$-acetylchitoheptaose but not those for chitinase and $\beta$-glucanase, nor histone H3, a gene nonresponsive to elicitor addition (Fig. 1).

Because two different organic acids that are considered to permeate membranes in their protonated form showed the same effects, the data strongly suggested that these acids induced their effects via cytoplasmic acidification. In order to exclude the possibility that the group A genes responded to the extracelluler acidification, we tested hydrochloric acid, which is considered to dissociate easily in the media. In the range of 1 to $5 \mathrm{mM}$, propionic acid was effective at all concentrations, whereas hydrochloric acid was effective only at $5 \mathrm{mM}$ (Fig. 2). Propionic acid at concentrations lower than $1 \mathrm{mM}$ or higher than $5 \mathrm{mM}$ showed no effects (data not shown). Further analysis by in vivo ${ }^{31} \mathrm{P}$-nuclear magnetic resonance (NMR) showed that the extent of acidification in the cytoplasm was dependent on the concentration of hydrochloric acid, i.e., hydrochloric acid at $5 \mathrm{mM}$ induced a higher extent of acidification (approximately 0.4 units) whereas $1 \mathrm{mM}$ induced a lower extent of acidification (approximately 0.1 units), indicating the correlation of gene expression to cytoplasmic acidification. It was also shown that the $\mathrm{pH}$ in the cytoplasm decreased by 0.5 units immediately after loading of propionic acid (Fig. $3 \mathrm{~A})$. These results support the idea that group A genes are expressed in response not to external acidification but to the cy-

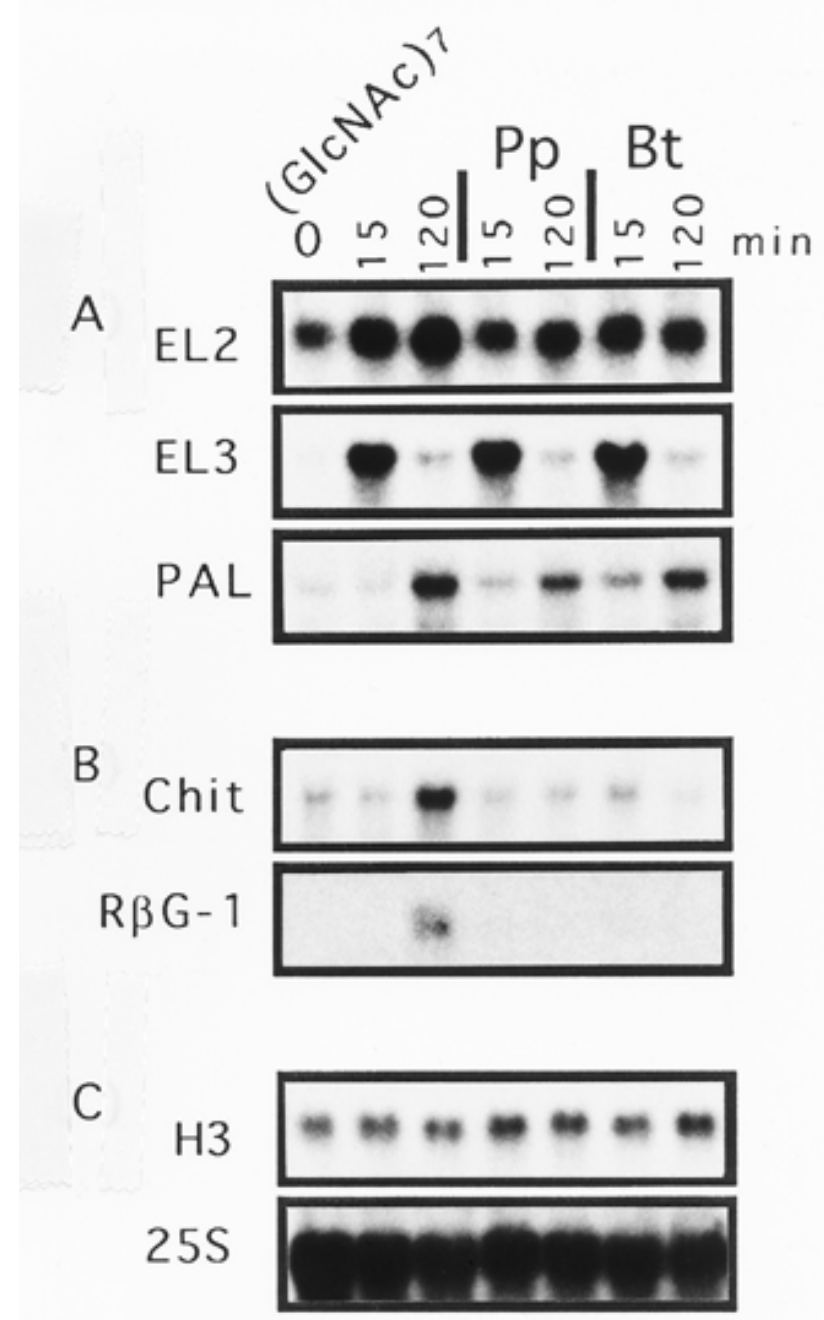

Fig. 1. Effects of acids on the accumulation of the mRNAs for elicitorresponsive genes. Rice cell suspensions were fed with $1.5 \mathrm{mM}$ propionic acid $(\mathrm{Pp})$ or butyric acid $(\mathrm{Bt})$ and incubated for the time indicated (minutes). Ten micrograms of total RNA was denatured with glyoxal, separated by electrophoresis in $1.4 \%$ agarose, and blotted to a nylon membrane, followed by hybridization with ${ }^{32} \mathrm{P}$-labeled probes for (A) $E L 2, E L 3$, phenylalanine ammonia-lyase $(P A L)$ (acid-responsive genes; group A), (B) Chit (chitinase), R $\beta \mathrm{G}-1$ ( $\beta$-1,3-glucanase) (acidnonresponsive genes; group B), (C) histone $\mathrm{H} 3$ and $25 \mathrm{~S}$ ribosomal RNA ( $25 \mathrm{~S}$ rRNA). As a positive control, $N$-acetylchitoheptaose at $1 \mu \mathrm{g} / \mathrm{ml}$ was added to the cell suspension and processed in the same way. (GlcNAc) $\mathrm{N}$-acetylchitoheptaose; H3, histone H3; 25S, 25S ribosomal RNA. 
toplasmic acidification of the cell. One possible side effect of these weak organic acids is a disruption of the membrane structure or function due to their lipophilic properties. However, as a control, tested $1 \%$ ( $\mathrm{vol} / \mathrm{vol})$ solution of ethanol did not induce the activation of any of these elicitor-responsive genes or cytoplasmic acidification (data not shown). Therefore, the most likely explanation is that organic acids induce specific mRNA by cytoplasmic acidification.

\section{Calyculin A induces both cytoplasmic acidification} and accumulation of $\mathbf{m R N A s}$ for group $A$ genes.

It has been reported that inhibitors of protein phosphatases of animal cells can provoke significant defense reactions in plant cells (Felix et al. 1994; Levine et al. 1994; MacIntosh et al. 1994; Kuchitsu et al. 1995). Using in vivo ${ }^{31} \mathrm{P}-\mathrm{NMR}$, we found that calyculin A, an inhibitor of protein phosphatases, also induces cytoplasmic acidification at slower speed than cytoplasmic acidification induced by $N$-acetylchitoheptaose or propionic acid. On the other hand, K-252a, a potent inhibitor

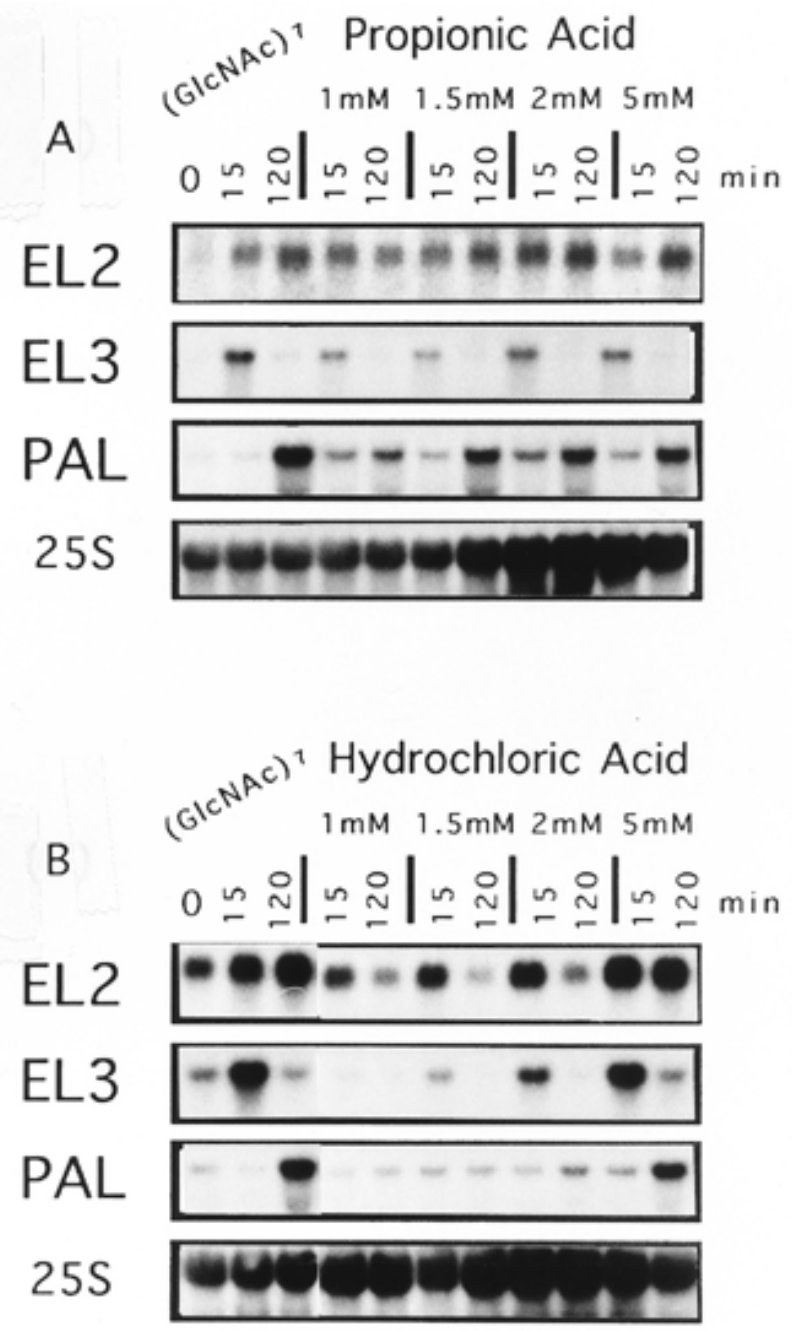

Fig. 2. Dose effects of propionic acid and hydrochloric acid on the induction of group A genes (EL2, EL3, phenylalanine ammonia-lyase $[P A L])$. Rice cell suspensions were fed with propionic acid (upper panel) or hydrochloric acid (lower panel) at concentrations indicated. Total RNA was isolated and analyzed by probing with group A genes as described in the legend to Figure 1. of Ser/Thr protein kinases, canceled the cytoplasmic acidification induced by $\mathrm{N}$-acetylchitoheptaose (Fig. 3B), indicating that cytoplasmic acidification is regulated by protein phosphorylation/dephosphorylation cycle. We observed that K-252a

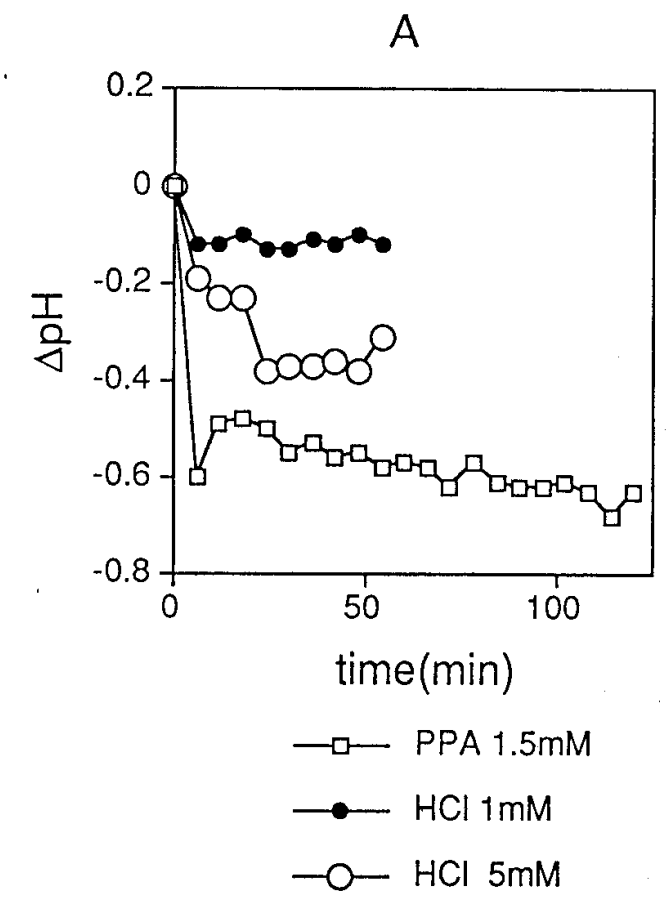

B

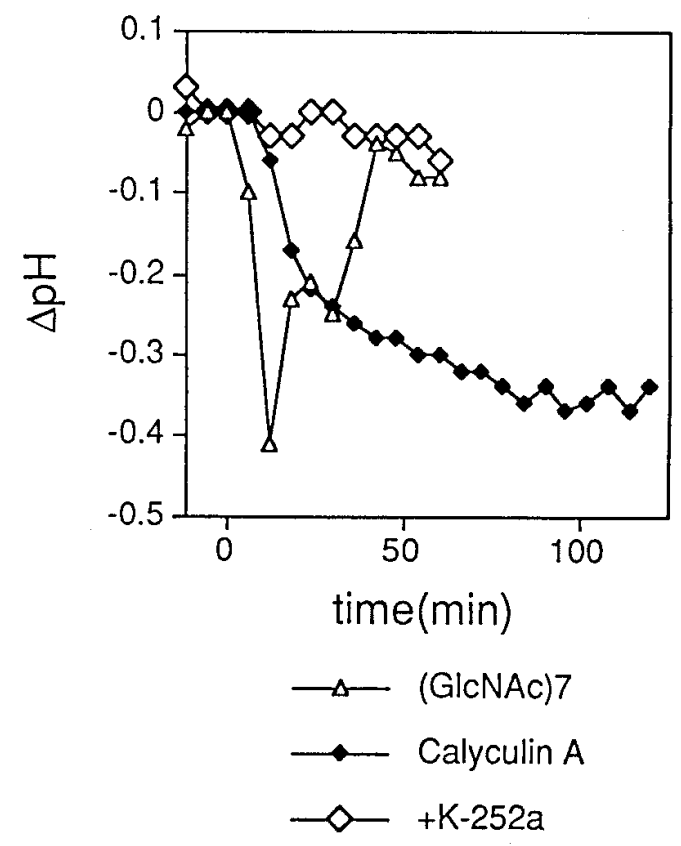

Fig. 3. Measurement of cytoplasmic $\mathrm{pH}$ by in vivo ${ }^{31} \mathrm{P}$-nuclear magnetic resonance (NMR) spectroscopy. About $2 \mathrm{~g}$ of rice cells was used for the measurement. Propionic acid, hydrochloric acid, calyculin A $(1 \mu \mathrm{M})$, or $N$-acetylchitoheptaose $(1 \mu \mathrm{g} / \mathrm{ml})$ was added to the circulating medium at time zero, and the NMR signal was measured for up to $2 \mathrm{~h}$. K-252a (10 $\mu \mathrm{M}$ ) was added $12 \mathrm{~min}$ before addition of $\mathrm{N}$-acetylchitoheptaose. 
did not inhibit the acidification induced by propionic acid (data not shown).

In order to test whether a protein phosphorylation/dephosphorylation cycle regulates the expression of elicitorresponsive genes, we tested calyculin A to induce these genes. Results showed that calyculin A induced the accumulation of mRNAs for group A but not group B genes with a time course comparable to that of the mRNA accumulation induced by $\mathrm{N}$ acetylchitoheptaose in our experimental system (Fig. 4).

\section{K-252a inhibits the accumulation of mRNAs}

for group A genes induced by propionic acid much less than it does that induced by $\mathbf{N}$-acetylchitoheptaose.

We tested the effect of $\mathrm{K}-252 \mathrm{a}$ on the accumulation of mRNAs for group A genes. Figure 5 shows that K-252a strongly inhibits mRNA accumulation induced by $\mathrm{N}$ acetylchitoheptaose. In contrast, K-252a showed a less in-

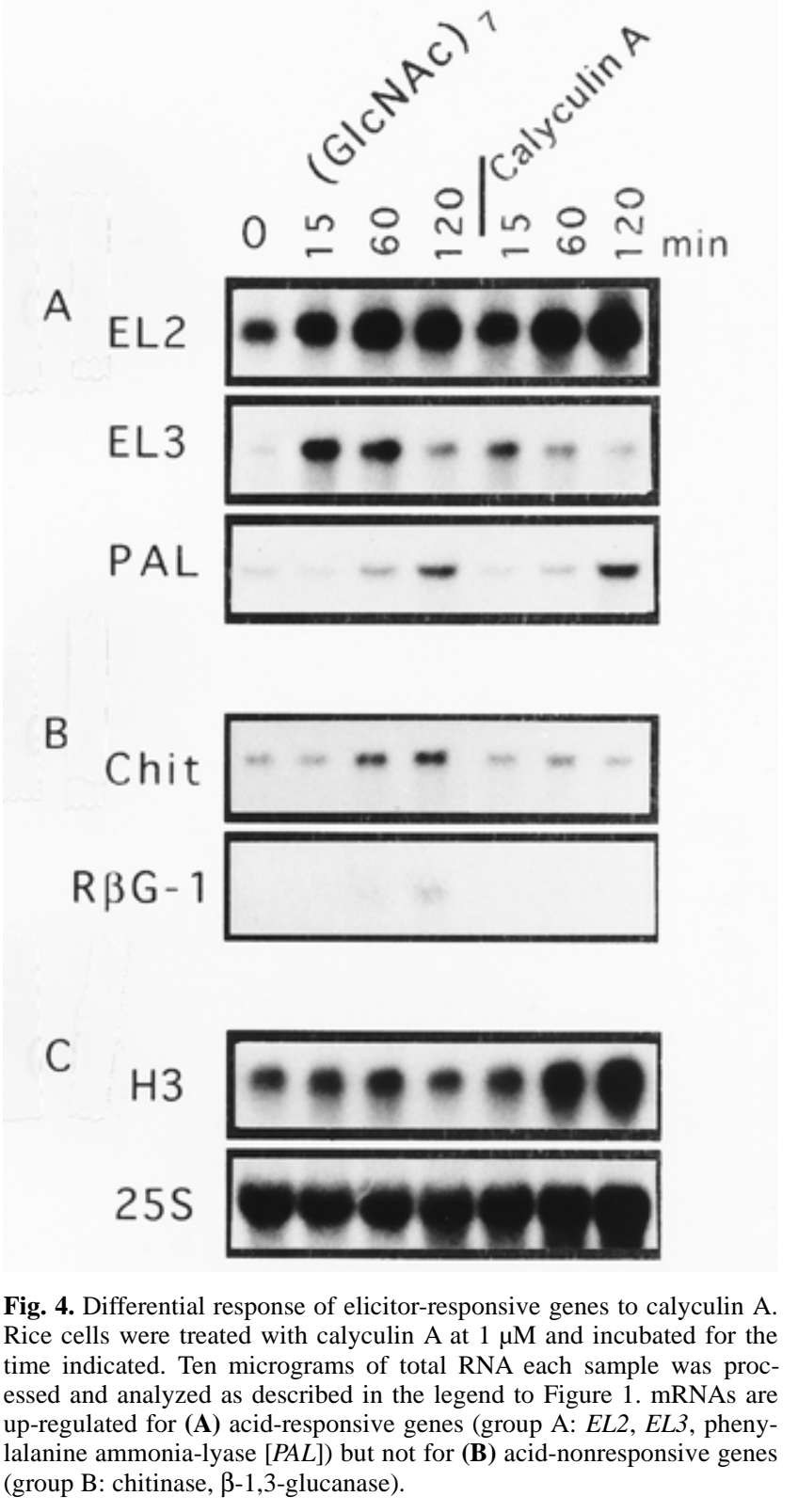

hibitory effect on gene activation induced by propionic acid. These results strongly suggest that the signal input by direct acidification of the cytoplasm by propionic acid bypassed the phosphorylation event(s) essential in the signal transduction pathway from $\mathrm{N}$-acetylchitoheptaose to the expression of group A genes.

\section{Propionic acid rapidly induces gene expression.}

Figure 6 shows the rapid accumulation of EL2 and EL3 mRNAs in response to propionic acid. The level of both mRNAs increased within 6 to $10 \mathrm{~min}$ after the addition of propionic acid. The time course of mRNA accumulations of $E L 2, E L 3$, and $P A L$ was quite similar to the time course of the accumulation induced by $N$-acetylchitoheptaose as previously reported (Minami et al. 1996). This result led us to speculate that the level of cytoplasmic $\mathrm{H}^{+}$could be a quick mediator of the elicitor signal.

\section{Treatment with propionic acid does not induce} the production of reactive oxygen species.

One of the major early responses by plant cells upon elicitation is the production of reactive oxygen species (for review see Baker and Orlandi 1995). Kuchitsu et al. (1995) showed the production of reactive oxygen species in suspensioncultured rice cells in response to $\mathrm{N}$-acetylchitooligosaccharides or calyculin A. Neither propionic acid nor butyric acid induced the production of hydrogen peroxide (Table 1), indicating that cytoplasmic acidification is not a signal leading to the production of reactive oxygen species.

\section{DISCUSSION}

Extensive studies have been performed to elucidate the signal transduction pathway from elicitors to the defense reactions. We have established a model system in which suspension-cultured rice cells specifically recognize $\mathrm{N}$-acetylchito-

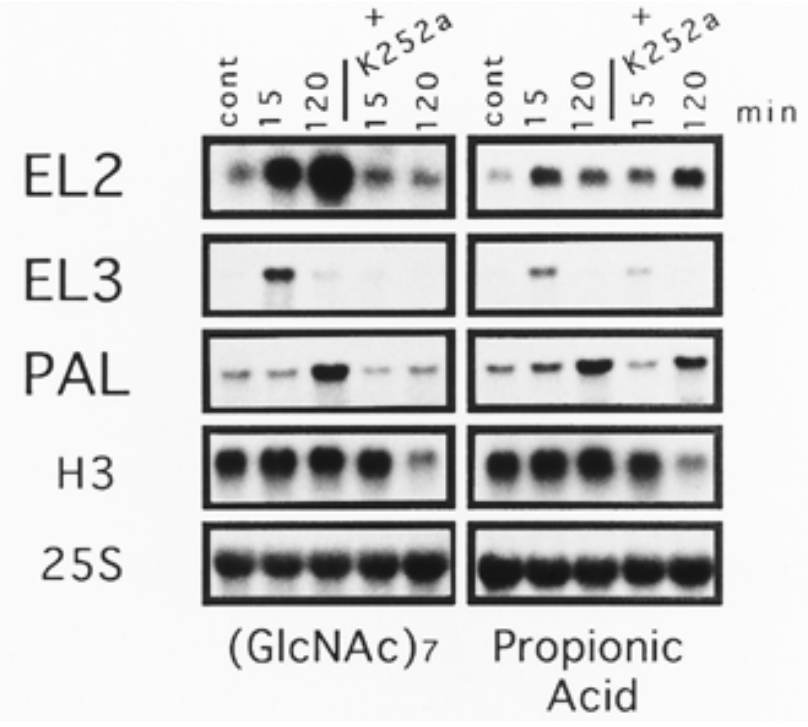

Fig. 5. Inhibition of the mRNA accumulations by K-252a. Rice cells were treated with $N$-acetylchitoheptaose $(1 \mu \mathrm{g} / \mathrm{ml})$ or propionic acid $(1.5$ $\mathrm{mM}) 10 \mathrm{~min}$ after addition of $\mathrm{K}-252 \mathrm{a}(10 \mu \mathrm{M})$ and incubated for the time indicated. Ten micrograms of total RNA from each sample was processed and analyzed as described in the legend to Figure 1. 
oligosaccharides as potent elicitors and exhibit a defined set of defense reactions (Yamada et al. 1993; Kuchitsu et al. 1993, 1995). Using several kinds of ${ }^{125}$ I-labeled derivatives of elicitor-active $N$-acetylchitoheptaose, we have been able to detect and characterize the high affinity binding site in the plasma membrane (Shibuya et al. 1993, 1996; Ito et al. 1997). We isolated two novel genes, EL2 and EL3, that responded to $\mathrm{N}$ acetylchitooligosaccharides within minutes (Minami et al. 1996), suggesting that these genes could be excellent molecular probes for the analysis of early signal transduction events. Taking advantage of these characteristics, we studied the physiological role of $\mathrm{H}^{+}$influx and protein phosphorylation and their relationship to the accumulation of mRNAs for elicitorresponsive genes and production of reactive oxygen species.

It has been observed that changes in fluxes of $\mathrm{Ca}^{2+}, \mathrm{H}^{+}, \mathrm{Cl}^{-}$, and $\mathrm{K}^{+}$occur at an early stage in the response to elicitors. Rapid alkalinization of the medium and concomitant acidification of the cytoplasm have been observed in suspensioncultured bean (Ojalvo et al. 1987), tobacco (Mathieu et al. 1991, 1996), and rice cells (Kuchitsu et al. 1997) in response to elicitor addition. Activation of $P A L$ and secondary metabolism including lignification were induced in cells treated with vanadate, an inhibitor of plasma membrane $\mathrm{H}^{+}$-ATPase, or $\mathrm{H}^{+}$ionophores for some plant species (Hattori and Ohta 1985; Steffens et al. 1989; Hagendoorn et al. 1990a, 1990b), suggesting that cytoplasmic acidification induced by these reagents could be a secondary signal leading to other cellular events (Guern et al. 1992). Our present study showed that the cytoplasmic acidification, which was directly induced by addition of propionic, butyric, or hydrochloric acid, induced the accumulation of mRNAs for elicitor-responsive genes with a time course comparable to that of the accumulation induced by $N$-acetylchitoheptaose (Figs. 1, 2, and 6). In suspensioncultured soybean cells, cytoplasmic acidification in response to elicitor was not observed in buffered media (Horn et al. 1992). In media where $\mathrm{pH}$ is kept constant, treatment of rice cells with $\mathrm{N}$-acetylchitoheptaose induced both group A and group B gene expression and the cytoplasmic acidification as observed in cells in nonbuffered media (data not shown). This fact might imply the occurrence of different systems for sensing the extracellular $\mathrm{pH}$ in soybean cells.

Propionic acid induced a sustainable acidification of the cytoplasm, whereas $\mathrm{N}$-acetylchitoheptaose induced transient acidification (Fig. 3). Both treatments exhibited the same effects on the accumulation of mRNAs for group A genes. In tobacco suspension-cultured cells, a chemically pure elicitor, oligogalacturonide, was shown to induce a transient acidification, whereas a crude elicitor fraction from Phytophthora megasperma induced a persistent acidification. Despite the difference in the profile of cytoplasmic acidification, en-

Table 1. Production of hydrogen peroxide by treatment with acids ${ }^{\mathrm{a}}$

\begin{tabular}{lcc}
\hline Treatments & & $\mathbf{H}_{\mathbf{2}} \mathbf{O}_{\mathbf{2}}$ (nmol per $\mathbf{g}$ of fresh weight) \\
\hline$N$-acetylchitoheptaose & $1 \mu \mathrm{g} / \mathrm{ml}$ & $767.5 \pm 23.9$ \\
Propionic acid & $1.5 \mathrm{mM}$ & $20.1 \pm 15.6$ \\
Butyric acid & $1.5 \mathrm{mM}$ & $18.4 \pm 9.8$ \\
No addition & - & $9.7 \pm 7.3$ \\
\hline
\end{tabular}

${ }^{a}$ Eighty milligrams of rice cells was suspended in $1 \mathrm{ml}$ of fresh medium and shaken at $25^{\circ} \mathrm{C}$ for $3 \mathrm{~h}$. At $15 \mathrm{~min}$ after addition of acids, the level of $\mathrm{H}_{2} \mathrm{O}_{2}$ in the medium was measured. As a positive control, $N$ acetylchitoheptaose at $1 \mu \mathrm{g} / \mathrm{ml}$ was used. hancements in the activities of $P A L$ and $o$-diphenolmethyl transferase were detected in both treatments (Guern et al. 1992). These observations lead us to speculate that the rapid decrease in the cytoplasmic $\mathrm{pH}$ may be a key to the induction of elicitor-responsive genes.

Calyculin A induced group A genes but not group B genes (Fig. 4). Taking into consideration the fact that calyculin A also induced the cytoplasmic acidification (Fig. 3), it is also suggested that calyculin A exerts its effects via cytoplasmic acidification. This idea is supported by the observation that group B genes are not responsive to acid (Fig. 1) or calyculin A (Fig. 4). However, we cannot eliminate the possibility that there is another signaling pathway from calyculin A to the gene activation in addition to the cytoplasmic acidification, as implied by the slight delay of the acidification by calyculin A compared with the cytoplasmic acidification by $N$-acetylchitoheptaose or propionic acid (Figure 3).

Inhibition by K-252a of the acid induction of mRNAs for group A genes was weaker than inhibition of the elicitor induction (Fig. 5). Therefore, the signals from externally loaded acid are likely to bypass the K-252a-accessible phosphorylation step(s) thought to regulate the cytoplasmic acidification in the signal transduction from $\mathrm{N}$-acetylchitooligosaccharides. In suspension-cultured tomato and tobacco cells, the involvement of protein phosphorylation/dephosphorylation step(s) in the $\mathrm{H}^{+}$flux has been suggested (Felix et al. 1993, 1994; Mathieu et al. 1996).

Treatments of rice cells with propionic acid or butyric acid did not induce the production of reactive oxygen species (Table 1). Production of reactive oxygen species induced by elicitors was shown to be regulated by protein phosphorylation/dephosphorylation cycle(s) (Schwacke and Hager 1992; Kuchitsu and Shibuya 1994; Levine et al. 1994; Kuchitsu et al. 1995; also see Baker and Orlandi 1995). Figure 7 illustrates a hypothetical model based on our results of the signal

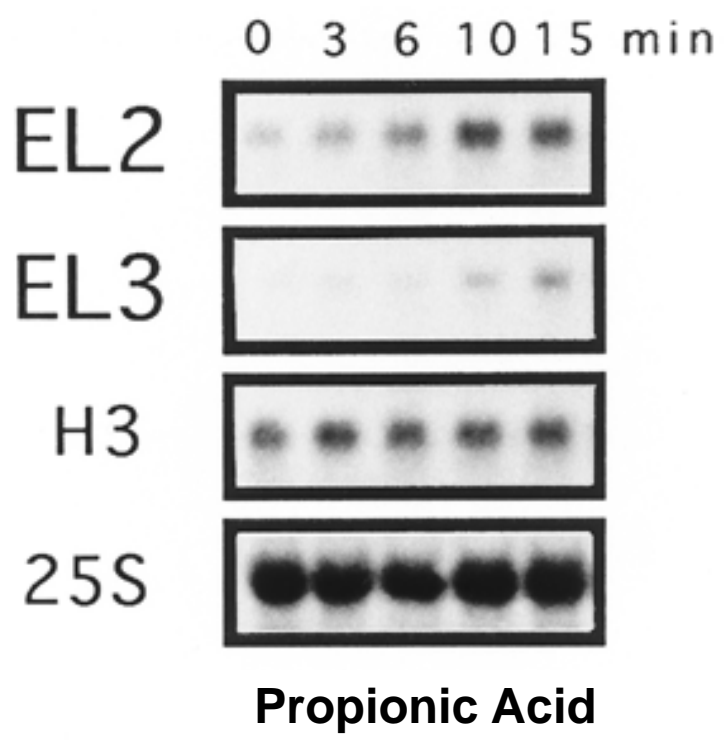

Fig. 6. Rapid accumulation of the mRNAs for $E L 2$ and $E L 3$ induced by propionic acid. Rice cells were treated with propionic acid at $1.5 \mathrm{mM}$ and incubated for the time indicated. Ten micrograms of total RNA from each sample was processed and analyzed as described in the legend to Figure 1. 
pathway from $\mathrm{N}$-acetylchitoheptaose to various defense responses. The model predicts that recognition of $\mathrm{N}$-acetylchitoheptaose induces a rapid phosphorylation of protein(s) that is involved in the production of reactive oxygen species and in the induction of $\mathrm{H}^{+}$influx. The resultant acidification of the cytoplasm serves as a signal for the activation of group A genes but not for the activation of group B genes nor the production of reactive oxygen species. The signaling pathway from propionic acid bypasses this step by introducing $\mathrm{H}^{+}$directly into the cytoplasm, resulting in mRNA accumulations of group A genes that are less sensitive to K-252a addition. The model does not require that the signal transduction from propionic acid does not involve protein phosphorylation, but only that such a phosphorylated site(s) is not easily accessible to $\mathrm{K}-252 \mathrm{a}$ in the experimental conditions tested. There is a possibility that the extra- and intracellular $\mathrm{pH}$ shift caused by propionic acid changes the conformation of protein kinase(s) or its substrate, resulting in a modified sensitivity to K-252a in the cells treated with propionic acid.

As shown in Figure 6, mRNAs for EL2 and EL3 accumulated in response to propionic acid as rapidly as to $N$ acetylchitoheptaose (Minami et al. 1996). Diffusion of $\mathrm{H}^{+}$ could act as a quick signal to the nucleus that causes transcriptional activation through a conformational change of chromatin structure. In cultured mammalian cells, intracellular acidification has been shown to cause phosphorylation of specific proteins that are located in the nucleus and assembled tightly in the chromatin structure and the activation of "early genes" including c-fos and c-myc (Isfort et al. 1993). Rapid phosphorylation of a $26-\mathrm{kDa}$ nuclear protein in cultured parsley cells was detected after treatment with elicitor (Dietrich et al. 1990). It is intriguing to speculate that the elicited rice cells transmit signals to nuclei via acidification of the cytoplasm and the nuclear matrix, resulting in the phosphorylation or dephosphorylation of a specific set of proteins, leading to the activation of elicitor-responsive genes.

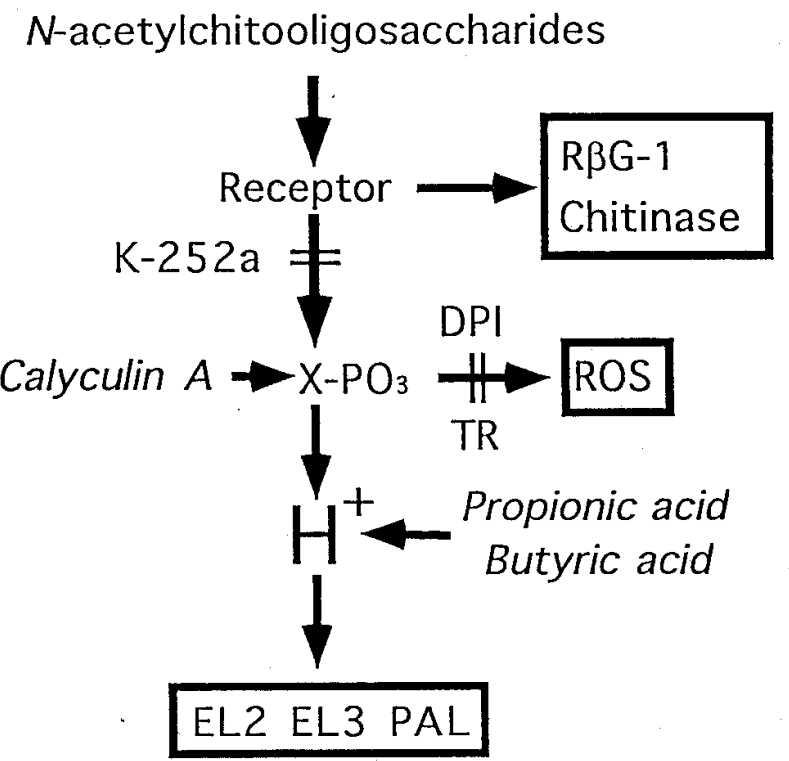

Fig. 7. Hypothetical model of the signal transduction from $N$-acetylchitoheptaose. X, putative phosphorylated factor(s) that plays essential roles in the elicitor-signaling; DPI, diphenylene iodinium; TR, tiron.
The level of the mRNA for histone $\mathrm{H} 3$ in suspensioncultured rice cells was down-regulated by K-252a (Fig. 5) and up-regulated by calyculin A (Fig. 4), suggesting that there is a protein phosphorylation/dephosphorylation cycle(s) involved in the regulation of histone $\mathrm{H} 3$ expression. The phosphorylated factors responsible for the level of histone $\mathrm{H} 3 \mathrm{mRNA}$ are likely to be different from those for $E L 2, E L 3$, and $P A L$, because histone $\mathrm{H} 3$ expression did not respond to $\mathrm{N}$ acetylchitoheptaose (Figs. 1, 5, and 6). The involvement of protein phosphorylation(s) in the regulation of plant and animal histone genes has been shown (Shen and Gigot 1997; see references therein).

Lawton et al. (1994) reported that a class of pathogenesisrelated (PR) proteins were inducible by treatment with hydrochloric acid or phosphoric acid in Arabidopsis thaliana plants. The physiological significance of the intracellular $\mathrm{pH}$ in signal transduction and its molecular mechanisms are still unclear. The data we obtained clearly indicate the biological significance of a $\mathrm{pH}$ change in the elicitor signaling. Identification of the factors involved in the transcriptional or posttranscriptional regulations of defense-related genes would be a great help in understanding how intracellular $\mathrm{pH}$ change acts as secondary signal.

\section{MATERIALS AND METHODS}

\section{Cell culture and treatments with inhibitors.}

Suspension-cultured rice cells (Oryza sativa cv. Nipponbare) were maintained at $25^{\circ} \mathrm{C}$ in modified N-6 medium, subcultured weekly as described by Kuchitsu et al. (1993). Inhibitors dissolved in $100 \mu \mathrm{l}$ of water or dimethyl sulfoxide were added to the cell suspension (approximately $0.5 \mathrm{~g}$ in fresh weight) in $10 \mathrm{ml}$ of culture medium 5 to $10 \mathrm{~min}$ before the addition of $\mathrm{N}$-acetylchitoheptaose or propionic acid.

\section{RNA isolation and Northern (RNA) blot hybridization.}

Total RNAs were isolated from the rice cells by the sodium dodecyl sulfate (SDS)-phenol method. Ten micrograms of total RNA was denatured with glyoxal, separated by electrophoresis in $1.4 \%$ (wt/vol) agarose gel, and blotted to nylon membranes (Biodyne A, Pole Co. Ltd., Port Washington, NY) according to the method of Thomas (1983). Membranes were hybridized with ${ }^{32} \mathrm{P}$-labeled cDNAs for EL2 and EL3 (Minami et al. 1996), $C P-1$ for rice PAL (Minami et al. 1989), $R C C-1$ for rice chitinase (Nishizawa et al. 1991), R $\beta \mathrm{G}-1$ for rice $\beta$ 1,3-glucanase (K. Yamada, R. Takai, H. Kaku, N. Shibuya, and E. Minami, unpublished results), or genomic DNA for wheat histone $\mathrm{H} 3$, which was a generous gift from Masaki Iwabuchi of the University of Kyoto (Tabata et al. 1984). Membranes were washed twice with $2 \times \mathrm{SSC}(1 \times \mathrm{SSC}$ is 0.15 $\mathrm{M} \mathrm{NaCl}$ plus $0.015 \mathrm{M}$ sodium citrate), $0.1 \% \mathrm{SDS}$ for $5 \mathrm{~min}$ at room temperature then twice with $0.1 \times \mathrm{SSC}, 0.1 \%$ SDS for 15 $\min$ at $60^{\circ} \mathrm{C}$. For hybridization with $25 \mathrm{~S}$ ribosomal RNA, a 1$\mathrm{kbp} E c o \mathrm{RI} / B a m \mathrm{HI}$ fragment was prepared from $p R R 217$, which was kindly supplied by F. Takaiwa of the National Institute of Agrobiological Resources (Takaiwa et al. 1984).

\section{In vivo ${ }^{31} \mathbf{P}$-NMR spectroscopy.}

Cytoplasmic $\mathrm{pH}$ was measured by in vivo ${ }^{31} \mathrm{P}-\mathrm{NMR}$ as described by Kuchitsu et al. (1997). Cells 4 days after subculture (approximately $1 \mathrm{~g}$ of fresh weight) were transferred into an 
NMR tube (10 mm diameter) after being washed with $\mathrm{N}-6$ medium excluding $\mathrm{KH}_{2} \mathrm{PO}_{4}, \mathrm{Fe}_{2} \mathrm{SO}_{4}, \mathrm{Na}_{2}$-EDTA, $\mathrm{MnSO}_{4}$, $\mathrm{ZnSO}_{4}, \quad \mathrm{CuSO}_{4}, \quad \mathrm{NaMoO}_{4}, \quad \mathrm{CoCl}_{2}, \quad$ and 2,4-D (2,4dichlorophenoxyacetic acid; NMR medium). The cells were incubated for $1 \mathrm{~h}$ at $25^{\circ} \mathrm{C}$ in NMR medium with $10 \%$ (vol/vol) $\mathrm{D}_{2} \mathrm{O}$ circulating by peristaric pump at $5 \mathrm{ml} / \mathrm{min}$. In vivo ${ }^{31} \mathrm{P}-$ NMR spectra were measured with a Varian VXR-500S spectrometer, operating at $202.3 \mathrm{MHz}$ at $25^{\circ} \mathrm{C}$ with $45^{\circ}$ pulses at a repetition rate of $0.2 \mathrm{~s}$. Methylene diphosphonate in Tris- $\mathrm{HCl}$ $(\mathrm{pH} 8.9)$ in a capillary tube was used as an internal standard. Intracellular $\mathrm{pH}$ was calculated according to the method of Roberts et al. (1981).

\section{Determination of hydrogen peroxide.}

Eighty milligrams of cells was resuspended in $1 \mathrm{ml}$ of fresh medium and incubated for $2 \mathrm{~h}$ in a shaker at $25^{\circ} \mathrm{C}$. After treatment with propionic acid $(1.5 \mathrm{mM})$ or $\mathrm{N}$-acetylchitoheptaose $(1 \mu \mathrm{g} / \mathrm{ml})$ for $15 \mathrm{~min}$, cells were centrifuged and the supernatant was kept on ice until the determination of hydrogen peroxide by the luminol method (Schwacke and Hager 1992).

\section{ACKNOWLEDGMENTS}

We are deeply grateful to Gary Stacey, Mostafa Rahbar, and Robert B. Day of the University of Tennessee and Kazuyuki Kuchitsu of the National Institute of Agrobiological Resources for their critical reading of manuscript, and to Masaki Iwabuchi of Kyoto University and Fumio Takaiwa of the National Institute of Agrobiological Resources for the kind supply of clones for wheat histone $\mathrm{H} 3$ and rice ribosomal RNA, respectively. We are indebted to Yuka Kumakura and Yoshiko Nawa for their excellent technical assistance and Naoko Ishii-Minami for continuous encouragement and helpful discussions. This work was supported in part by a grant from the Ministry of Agriculture, Forestry and Fishery, and the Agency of Science and Technology of Japan.

\section{LITERATURE CITED}

Atkinson, M. M., Midland, S. L., Sims, J. J., and Keen, N. T. 1996. Syringolide 1 triggers $\mathrm{Ca}^{2+}$ influx, $\mathrm{K}^{+}$efflux, and extracellular alkalization in soybean cells carrying the disease-resistance gene Rpg4. Plant Physiol. 112:297-302.

Baker, C. J., and Orlandi, E. W. 1995. Reactive oxygen in plant pathogenesis. Annu. Rev. Phytopathol. 33:299-321.

Basse, C. W., Fath, A., and Boller, T. 1993. High affinity binding of glycopeptide elicitor to tomato cells and microsomal membranes and displacement by specific glucan suppressers. J. Biol. Chem. 268: 14724-14731.

Baureithel, K., Felix, G., and Boller, T. 1994. Specific, high affinity binding of chitin fragments to tomato cells and membranes. Competitive inhibition of binding by derivatives of chitooligosaccharides and a Nod factor of Rhizobium. J. Biol. Chem. 269:17931-17938.

Boller, T. 1995. Chemoperception of microbial signals in plant cells. Annu. Rev. Plant Physiol. Plant Mol. Biol. 46:189-214.

Cheong, J.-J., and Hahn, M. G. 1991. A specific, high-affinity binding site for the hepta- $\beta$-glucoside elicitor exists in soybean membranes. Plant Cell 3:137-147.

Cote, F., and Hahn, M.G. 1994. Oligosaccharins: Structures and signal transduction. Plant Mol. Biol. 26:1379-1411.

Dietrich, A., Mayers, J. E., and Hahlbrock, K. 1990. Fungal elicitor triggers rapid, transient, and specific protein phosphorylation in parsley cell suspension cultures. J. Biol. Chem. 265:6360-6368.

Dixon, R. A., and Harrison, M. J. 1990. Activation, structure, and organization of genes involved in microbial defense in plants. Adv. Genet. 28:165-234.

Dixon, R. A., Harrison, M. J., and Lamb, C. J. 1994. Early events in the activation of plant defense responses. Annu. Rev. Phytopathol. 32: 479-501.
Ebel, J., and Cosio, E. G. 1994. Elicitors of plant defense responses. Int. Rev. Cytol. 148:1-36.

Farmer, E. E., Moloshok, T. D., Sacton, M. J., and Ryan, C. A. 1991. Oligosaccharide signaling in plants. Specificity of oligouronideenhanced plasma membrane protein phosphorylation. J. Biol. Chem. 266:3140-3145.

Felix, G., Grosskopf, D. G., Regenass, M., and Boller, T. 1991. Rapid changes of protein phosphorylation are involved in transduction of the elicitor signal in plant cells. Proc. Natl. Acad. Sci. USA 88:88318834.

Felix, G., Regenass, M., and Boller, T. 1993. Specific perception of subnanomolar concentrations of chitin fragments by tomato cells: Induction of extracellular alkalinization, changes in protein phosphorylation, and establishment of a refractory state. Plant J. 4:307-316.

Felix, G., Regenass, M., Spanu, P., and Boller, T. 1994. The protein phosphatase inhibitor calyculin A mimics elicitor action in plant cells and induces rapid hyperphosphorylation of specific proteins as revealed by pulse labeling with $\left[{ }^{33} \mathrm{P}\right]$ phosphate. Proc. Natl. Acad. Sci. USA 91:952-956.

Grosskopf, D. G., Felix, G., and Boller, T. 1990. K-252a inhibits the response of tomato cells to fungal elicitors in vivo and their microsomal protein kinase in vitro. FEBS Lett. 275:177-180.

Guern, J., Felle, H., Mathieu, Y., and Kurkdjian, A. 1991. Regulation of intracellular $\mathrm{pH}$ in plant cells. Int. Rev. Cytol. 127:111-173.

Guern, J., Mathieu, Y., Thomine, S., Jouanneau, J.-P., and Beloeil, J.-C. 1992. Plant cells counteract cytoplasmic pH changes but likely use these $\mathrm{pH}$ changes as secondary messages in signal perception. Curr. Top. Plant Biochem. Physiol. 11:249-269.

Hagendoorn, M. J. M., Poortinga, A. M., Sang, H. W. W. F., van der Plas, L. H. W., and van Walraven, H. S. 1990a. Effect of elicitors on the plasmamembrane of Petunia hybrida cell suspensions - Role of $\Delta \mathrm{pH}$ in signal transduction. Plant Physiol. 96:1261-1267.

Hagendoorn, M. J. M., Traas, T. P., Boon, J. J., and van der Plas, L. H. W. 1990b. Orthovanadate induced lignin production, in batch and continuous cultures of Petunia hybrida. J. Plant Physiol. 137:72-80.

Hattori, T., and Ohta, Y. 1985. Induction of phenylalanine ammonialyase activation and isoflavone glucoside accumulation in suspensioncultured cells of red bean, Vigna angularis, by phytoalexin elicitors, vanadate, and elevation of medium pH. Plant Cell Physiol. 26:11011110 .

Horn, M. A., Meadows, R. P., Apostol, I., Jones, C. R., Gorenstein, D. G., Heinstein, P. F., and Low, P. S. 1992. Effect of elicitation and changes in extracellular $\mathrm{pH}$ on the cytoplasmic and vacuolar $\mathrm{pH}$ of suspension-cultured soybean cells. Plant Physiol. 98:680-686.

Isfort, R. J., Cody, D. B., Asquith, T. N., Ridder, G. M., Stuard, S. B., and Leboeuf, R. A. 1993. Induction of protein phosphorylation, protein synthesis, immediate-early-gene expression and cellular proliferation by intracellular pH modulation. Eur. J. Biochem. 213:349-357.

Ito, Y., Kaku, H., and Shibuya, N. 1997. Identification of a high-affinity binding protein for $\mathrm{N}$-acetylchitooligosaccharide elicitor in the plasma membrane of suspension-cultured rice cells by affinity labeling. Plant J. 12:347-356.

Kikuyama, M., Kuchitsu, K., and Shibuya, N. 1997. Membrane depolarization induced by $N$-acetylchitooligosaccharide elicitor in suspension-cultured rice cells. Plant Cell Physiol. 38:902-909.

Kuchitsu, K., Kikuyama, M., and Shibuya, N. 1993. N-acetylchitooligosaccharides, biotic elicitor for phytoalexin production, induce transient membrane depolarization is suspension-cultured rice cells. Protoplasma 174:79-81.

Kuchitsu, K., Kosaka, H., Shiga, T., and Shibuya, N. 1995. EPR evidence for generation of hydroxyl radical triggered by $\mathrm{N}$-acetylchitooligosaccharide elicitor and a protein phosphatase inhibitor in suspension-cultured rice cells. Protoplasma 188:138-142.

Kuchitsu, K., and Shibuya, N. 1994. N-acetylchitooligosaccharides, specific fungal elicitor for defense responses, induce transient generation of reactive oxygen species in suspension-cultured rice cells. Pages 255-256 in: Frontiers of Reactive Oxygen Species in Biology and Medicine K. Asada and T. Yoshikawa, eds. Elsevier Science, Amsterdam.

Kuchitsu, K., Yazaki, Y., Sakano, K., and Shibuya, N. 1997. Transient cytoplasmic $\mathrm{pH}$ change and ion fluxes through the plasma membrane triggered by $\mathrm{N}$-acetylchitooligosaccharide elicitor in suspensioncultured rice cells. Plant Cell Physiol. 38:1012-1018.

Lawton, K.A., Potter, S. L., Ukens, S., and Ryals, J. 1994. Acquired re- 
sistance signal transduction in Arabidopsis is ethylene independent. Plant Cell 6:581-588.

Levine, A., Tenhaken, R., Dixon, R., and Lamb, C. 1994. $\mathrm{H}_{2} \mathrm{O}_{2}$ from the oxidative burst orchestrated the plant hypersensitive disease resistance response. Cell 79:583-593.

MacIntosh, C., Lyon, G. D., and MacIntosh, R. W. 1994. Protein phosphatase inhibitors activate anti-fungal defense responses of soybean cotyledons and cell cultures. Plant J. 5:137-147.

Mathieu, Y., Kurkdjian, A., Xia, H., Guern, J., Koller, A., Spiro, M. D., O'Neill, M., Albersheim, P., and Darville, A. 1991. Membrane responses induced by oligogalacturonides in suspension-cultured tobacco cells. Plant J. 1:333-343.

Mathieu, Y., Lapous, D., Thomine, S., Lauriere, C., and Guern, J. 1996. Cytoplasmic acidification as an early phosphorylation-dependent response of tobacco cells to elicitors. Planta 199:416-424.

Mayer, M. G., and Ziegler, E. 1988. An elicitor from Phytophthora megasperma f. sp. glycinea influences the membrane potential of soybean cotyledonary cells. Physiol. Mol. Plant Pathol. 33:397-407.

Minami, E., Kuchitsu, K., He, D.-Y., Kouchi, H., Midoh, N., Ohtsuki, Y., and Shibuya, N. 1996. Two novel genes rapidly and transiently activated in suspension-cultured rice cells by treatment with $\mathrm{N}$-acetylchitoheptaose, a biotic elicitor for phytoalexin production. Plant Cell Physiol. 37:563-567.

Minami, E., Ozeki, Y., Matsuoka, M., Koizuka, N., and Tanaka, Y. 1989. Structure and some characterization of the gene for phenylalanine ammonia-lyase from rice plants. Eur. J. Biochem. 185:19-25.

Nishizawa, Y., and Hibi, T. 1991. Rice chitinase gene: cDNA cloning and stress-induced expression. Plant Sci. 76:211-218.

Nürnberger, T., Nennstiel, D., Jabs, D., Sacks, W. R., Hahlbrock, K., and Sheel, D. 1994. High-affinity binding of a fungal oligopeptide elicitor to parsley plasma membranes triggers multiple defense responses. Cell 78:449-460

Ojalvo, I., Rokem, S., Navon, G., and Goldberg, I. 1987. ${ }^{31}$ P NMR study of elicitor treated Phaseolus vulgaris cell suspension cultures. Plant Physiol. 85:716-719.

Roberts, J. K. M., Jardetzky, N. W., and Jardetzky, O. 1981. Intracellular $\mathrm{pH}$ measurements by ${ }^{31} \mathrm{P}$ nuclear magnetic resonance. Influence of fac- tors other than $\mathrm{pH}$ on ${ }^{31} \mathrm{P}$ chemical shifts. Biochemistry 20:5389-5394.

Rushton, P. J., Torres, J. T., Parniske, M., Wernert, P., Hahlbrock, K., and Sommsich, I. 1996. Interaction of elicitor-induced DNA-binding proteins with elicitor response elements in the promoters of parsley PR1 genes. EMBO J. 15:5690-5700.

Schultze, M., Kondorosi, E., Ratet, P., Buire, M., and Kondorosi, A. 1994. Cell and molecular biology of rhizobium-plant interactions. Int. Rev. Cytol. 156:1-75.

Schwacke, R., and Hager, R. 1992. Fungal elicitors induce a transient release of reactive oxygen species from cultured spruce cells that is dependent on $\mathrm{Ca}^{2+}$ and protein-kinase activity. Planta 187:136-141.

Shen, W. H., and Gigot, C. 1997. Protein complexes binding to cis elements of the plant histone gene promoters: multiplicity, phosphorylation and cell cycle alteration. Plant Mol. Biol. 33:367-379.

Shibuya, N., Ebisu, N., Kamada, Y., Kaku, H., Cohn, J., and Ito, Y. 1996. Localization and binding characteristics of a high-affinity binding site for $N$-acetylchitooligosaccharide elicitor in the plasma membrane from suspension-cultured rice cells suggest a role as a receptor for the elicitor signal at the cell surface. Plant Cell Physiol. 37:894-898.

Shibuya, N., Kaku, H., Kuchitsu, K., and Maliarik, M. J. 1993. Identification of a novel high-affinity binding site for $N$-acetylchitooligosaccharide elicitor in the membrane fraction from suspension-cultured rice cells. FEBS Lett. 329:75-78.

Steffens, M., Ettl, F., Kranz, D., and Kindl, H. 1989. Vanadate mimics effects of fungal cell wall in eliciting gene activation in plant cell cultures. Planta 177:160-168.

Tabata, T., Fukasawa, M., and Iwabuchi, M. 1984. Nucleotide sequence and genomic organisation of a wheat histone H3 gene. Mol. Gen. Genet. 196:397-400.

Takaiwa, F., Oono, K., and Sugiura, M. 1984. The complete nucleotide sequence of a rice 17S rRNA gene. Nucleic Acids Res. 12:5441-5448.

Thomas, P. S. 1983. Hybridization of denatured RNA transferred or dotted to nitrocellulose paper. Methods Enzymol. 100:255-256.

Yamada, A., Shibuya, N., Kodama, O., and Akatsuka, T. 1993. Induction of phytoalexin formation in suspension-cultured rice cells by $N$ acetylchitooligosaccharides. Biosci. Biotech. Biochem. 57:405-409. 